\title{
EVALUATION OF FACTORS AFFECTING RISK IN REAL ESTATE INDUSTRY BY RELATIVELY IMPORTANCE INDEX METHOD
}

\author{
Parekh Varunkumar Jagdishbhai ${ }^{1 *}$ \\ *lCivil engineering department, Gujarat Technological UniversityVarun211991@ gmail.com
}

*Corresponding Author: -

Email:Varun211991@gmail.com

\begin{abstract}
: -
Real estate industry is fragmented, very sensitive to the economic cycles \& political environment, and has a significantly high rate of business failure. More than 50\% of all the real estate businesses have failed within the first five years as risks associated with their startup are not being considered. Business failure is an extremely disruptive force especially in case of construction industry. Previous studies on construction project risk management (PRM) have focused on the project level rather than the enterprise level. Enterprise Risk Management (ERM) is a process affected by an entity's board of directors, management and other personnel applied in a creating strategies across the enterprise. The objective of this study was to identify and assess the risk associated with the residential real estate business and also to formulate an enterprise risk management model.
\end{abstract}

Keywords: - "Real Estate”, "Risk Management", "Residential Real Estate”, "Risk Management Model".

\section{(c) (오 (i)}




\section{INTRODUCTION}

Real estate Industry plays a major role in the economic growth of a nation and occupies a pivotal position in the nation's development plans with the second largest contributor to the GDP which employs a work force of nearly 35 million and its market size is worth about INR 6, 70, 778 crores (Service Sector). Business failure, collapse and bankruptcy are common terms in the industry due to the many risks inherited in how the industry operates. Throughout the world, the relative ease of entry gives rise to a large number of construction companies competing fiercely in the market exposing many of them to business failure. According to (responders of the residential real estate of Vadodara city), more than 50\% of all the real estate businesses failed within the first five years since the risks associated with their startup are not being considered.

Business failure is an extremely disruptive force especially in case of construction industry. For any business startup, it is important to have proper business plan that suits the industry best. A professional business plan should include a detailed discussion of business risks and challenges. It will be impractical to identify and address all possible type of risk in a business plan, however it should consider the most critical ones and indicate how management will mitigate their potential impact on business operations.

As businesses grow periodically, risks associated with it grow at the same rate, together with new field of risk management being opened up. Thus, organizations' risk management adapts to the specialized risk by a more integrated approach: Enterprise Risk Management (Duong). While traditional risk management views risk as individual hazards, Enterprise Risk Management puts risks in the context of business strategy, then build a portfolio of risk development (Quinn). Organizations that vigorously interpret the results of their risk assessment process set a foundation for establishing an effective enterprise risk management (ERM) program and are better positioned to capitalize on opportunities as they arise. In the long run, this capability will help steer a business toward measurable, lasting success in today's ever-changing business environment (Atkinson, Joe; Jourdan, Catherine).

Complexity of various phases involved in real estate business (like land acquisition, Risk assessment, Planning and Construction, Marketing, Finalization of document, Handing over etc.) leads to business failure. In case of real estate industry, usually the study of construction project risk assessment is carried out. The study regarding business start-up risk assessment has not been given much attention.

\section{Objectives}

1. To identify and assess the risks associated with the mitigation measures for the business.

\section{Scope}

Scope of study is restricted to residential real estate industry of Vadodara city area, Gujarat, India only.

\section{Literature review}

\section{Risk Management and Real Estate Industry}

Real estate industry is fragmented, very sensitive to the economic cycles and political environment, and has a significantly high rate of business failure. There are various decision making model which helps decision maker to identify the various risks and project the potential results but none of them can solely and perfectly do so. Similarly, every business startup involves some degree of risk and it is impossible to avoid all risk when starting a business, careful planning can help get businesses up and running with a minimal amount of risk. Risk management not only prevents organizations from entering a dangerous and uncertain territory, which could lead to a catastrophic failures, but also ensure the development and growth of the business. The depth and clarity with which a risk is defined is critical for risk management (Tularam and Attili).

The process of assessing and managing these risks involves identification of negative events, their likelihood \& potential impact of such events and also focuses on reducing the likelihood that these negative events will occur and increasing the likelihood that positive outcomes will be realized.

\section{Traditional Risk Management v/s Enterprise Risk Management}

1. Encompasses all areas of organizational exposure to risk (financial, operational, reporting, compliance, governance, strategic, reputational, etc.);

2. Prioritizes and manages those exposures as an interrelated risk portfolio rather than as individual "silos";

3. Evaluates the risk portfolio in the context of all significant internal and external environments, systems, circumstances, and stakeholders;

4. Recognizes that individual risks across the organization are interrelated and can create a combined exposure that differs from the sum of the individual risks;

5. provides a structured process for the management of all risks, whether those risks are primarily quantitative or qualitative in nature;

6. Views the effective management of risk as a competitive advantage; and

7. Seeks to embed risk management as a component in all critical decisions throughout the organization. Enterprise Risk Management

ERM is a process, affected by an entity's board of directors, management, and other personnel, applied in a strategy setting and across the enterprise. It is designed to identify potential events that may affect the entity, to manage risk within its risk 
appetite, and to provide reasonable assurance regarding the achievement of entity objectives (Committee of Sponsoring Organizations of the Tread way Commission). Academics and industry commentators argue that ERM benefits firms by decreasing earnings and stock price volatility, reducing external capital costs, increasing capital efficiency, and creating synergies between different risk management activities (Hoyt, Moore and Liebenberg). In simple terms, ERM is said to promote increased risk awareness that facilitates better operational and strategic decision making.

\section{Risk Categories and Risks Identified through Literature Review}

The identification of events that could go wrong results in losses or not achieving the organization's goals. This process depends on the experiences and imagination of the participants in the risk identification process (Deposit Insurance Corporation of Ontario). TABLE. I DIFFERENT REAL ESTATE RISK CATEGORIES

\begin{tabular}{|c|c|}
\hline Risk Categories & Associated Risk \\
\hline Technical Risk & $\begin{array}{l}\text { Incomplete design, Appropriateness of specifications, uncertainty over } \\
\text { sources of material availability, Design updating, checklist and } \\
\text { methodology problems. }\end{array}$ \\
\hline $\begin{array}{l}\text { Human Resources } \\
\text { Management } \\
\text { Related Risk }\end{array}$ & $\begin{array}{l}\text { Unavailability manpower, employee retaining, employee dedication, } \\
\text { performance from employee. }\end{array}$ \\
\hline Political Risk & $\begin{array}{c}\text { Contractual risk, legislation compliance, retaining the employees, change in } \\
\text { building bylaws, change in zoning code, environmental regulation, revision } \\
\text { of taxation code, change in accounting rule. }\end{array}$ \\
\hline Financial Risk & $\begin{array}{l}\text { Availability \& fluctuation in foreign exchange, delay in of payments, } \\
\text { inflation risk, local taxes, repatriation of funds, availability of funds, capital } \\
\text { budgeting risk, capital structural risk, interest rate risk, valuation risk. }\end{array}$ \\
\hline Strategic Risk & $\begin{array}{l}\text { Competitive risk, administration risk/ corporate governance, reputation } \\
\text { risk/ ability to survive in market, innovation risk, partnership risk, property } \\
\text { management, information for decision making risk, information technology } \\
\text { risk, record management risk, communication risk. }\end{array}$ \\
\hline Operational Risk & $\begin{array}{l}\text { Availability of labour, material, machinery, technological risk, design risk, } \\
\text { timely completion risk, production risk, hazard risk, functional obsolesce. }\end{array}$ \\
\hline Marketing Risk & $\begin{array}{l}\text { Fluctuation of pricing, fluctuation of process, methodology of production, } \\
\text { distribution risk, efficiency risk. }\end{array}$ \\
\hline
\end{tabular}

\section{Research Gap}

Based on the literature review done of the past researchers it was found that

1. Most previous studies on construction project risk management (PRM) have focused on the project level rather than the enterprise level.

2. Enterprise risk management (ERM) has been the topic of increased media attention in recent years. Many organizations have implemented ERM programs; consulting firms have established specialized ERM units; and universities have developed ERM-related courses and research centers. Enterprise Risk Management related researches have not been carried out in real estate sector in Gujarat region it is not so popular in India as well.

\section{DATA COLLECTION INTRODUCTION}

The primary objective of this study was to identify and assess the various risks associated with the residential real estate projects of Vadodara city region only. The data collected was analyzed to identify the unacceptable risks and to propose the Enterprise Risk Management model. For this, a questionnaire survey was done based on the risk identified through literature review and brainstorming. After identifying the various risks, two suitable Likert scale was decided to give a score to the likelihood of occurrence and impact of each risk of residential real estate business.

\section{Methodology}

Questionnaire consists of 7 different risk categories and 49 types of risk associated with the housing business. In data collection, rating about the likelihood of occurrence and impact of each risk was collected. To rate the likelihood of occurrence and impact of each risk two types of Likert scale was selected. Two different rating scales are shown below: 
TABLE II: SCALE OF RELATIVE IMPORTANT

\begin{tabular}{|c|c|}
\hline Scale & Importance \\
\hline 1 & Not important \\
\hline 2 & Somewhat important \\
\hline 3 & Important \\
\hline 4 & Very important \\
\hline
\end{tabular}

Once the questionnaire was developed, Pilot study has been carried out to validate the questionnaire.

Based on the validated questionnaire, survey was carried out to collect the data.

Based on 95\% confidence level, 10\% confidence interval and population size 385 (Approx.), Sample size of 215 respondents were selected.

\section{DATA ANALYSIS}

\section{Expected Monetary Value Method}

The data collected was assessed through expected monetary value method to quantitatively prioritize a risk. Expected monetary value method is used to prioritize the risks with the highest probability of occurrence or the risks with the greatest monetary impact. During data collection likelihood of occurrence and Impact for each factor was rated in the scale of 1 (Very Low) to 5 (Very High) and 1 (Not Significant) to 5 (Extremely Significant) respectively.

Table III: RESULT OF DATA ANALYSIS

\begin{tabular}{|c|c|c|c|c|}
\hline $\begin{array}{c}\text { Significance } \\
\text { Level }\end{array}$ & Ranking & Risk & $R I I$ & Risk category \\
\hline Very High & 1 & Incomplete design & 0.8269 & \multirow[b]{2}{*}{ Technical Risk } \\
\hline Very High & 2 & $\begin{array}{l}\text { Checklist and } \\
\text { methodology } \\
\text { problem }\end{array}$ & 0.80635 & \\
\hline Very High & 1 & $\begin{array}{l}\text { Employee } \\
\text { dedication }\end{array}$ & 0.81429 & \multirow{2}{*}{$\begin{array}{c}\text { Human resource } \\
\text { management } \\
\text { related risk }\end{array}$} \\
\hline Very High & 2 & Employee retaining & 0.75397 & \\
\hline Very High & 1 & Contractual risk & 0.80556 & Political risk \\
\hline Very High & 2 & $\begin{array}{c}\text { Change in building } \\
\text { bylaws }\end{array}$ & 0.80079 & \\
\hline Very High & 1 & Delay in payment & 0.76111 & \multirow{2}{*}{ Financial risk } \\
\hline Very High & 2 & Local taxes & 0.70079 & \\
\hline Very High & 1 & Communication risk & 0.82778 & \multirow{2}{*}{ Stratagical risk } \\
\hline Very High & 2 & Competitive risk & 0.79921 & \\
\hline Very High & 1 & $\begin{array}{c}\text { Timely complication } \\
\text { risk }\end{array}$ & 0.80238 & \multirow[t]{2}{*}{ Operational risk } \\
\hline Very High & 2 & Hazard risk & 0.79841 & \\
\hline Very High & 1 & Efficiency risk & 0.78095 & \multirow{2}{*}{ Marketing risk } \\
\hline Very High & 2 & Distribution risk & 0.72063 & \\
\hline
\end{tabular}

\section{Monte Carlo Simulation Method}

From the ranking provided, most severe risks in each category was selected to identify the contingency that should be included so that the budget level will be achieved with a certain degree of confidence. For that expert survey of 5 experts was carried out. In expert survey, Data regarding the base cost associated with the most severe risk that company should have kept as a risk cost in total project cost as well as the data regarding the minimum value and maximum value for most severe risk was collected. Assumed probable cost of the project was 100 crore.

\section{Output of Monte Carlo Simulation}

The output of Monte Carlo simulation shows that when simulation is done at $95 \%$ of confidence, total risk cost changes as shown below:

- Total Risk Cost of a 100 crore project: 1170 Lacs

- Total Risk Cost at 99 \% confidence: 1282 Lacs

- Total Risk Cost at $95 \%$ confidence: 1247 Lacs

- Total Risk Cost at $90 \%$ confidence: 1028.7 Lacs

- Contingency @ 95\% confidence: 77 Lacs

- \% Contingency: $6.59 \%$ 


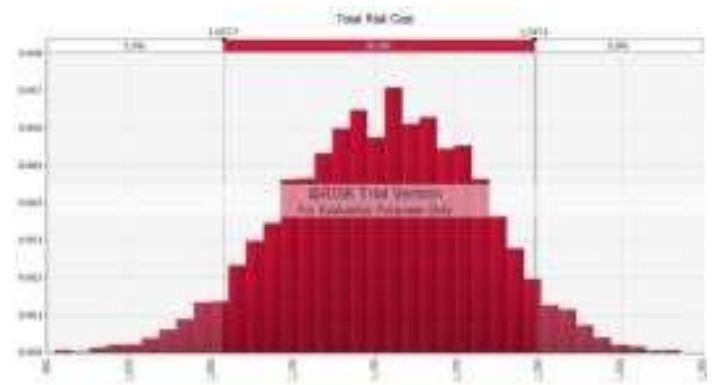

Fig. 1 Simulation Result Graph of Total Risk cost"

\section{Conclusion}

From the analysis done it was found that,

1.The major risk categories that any organization of residential real estate business must consider during their conceptualization stage are given in "Table I: Risk Categories and Associated Risks" on page no 2.

2. From the results of EMV of likelihood of occurrence \& impact, risk severity of each risk was calculated. From the risk severity and risk assessment matrix most severe risks in each category was found shown in "Table III: Result of data analysis on page no.3" .

3. From the expert survey it was found that in a residential project of 100 crore, approx. $11.7 \%$ of cost is kept for total risk assessment and management for the most severe risks. From the data analysis it was found that at $95 \%$ confidence cost for risk assessment and management may rise up to $12.47 \%$ and at $99 \%$ confidence it may rise up to $12.82 \%$. Simulation results are shown in "Figure No. 1: Simulation Result Graph of Total Risk cost" on page no 4. Monte Carlo simulation model for each risk was produced which shows the contingency required for each risks.

\section{Future scope}

This research mainly focuses on the residential real estate business in real estate sector of Vadodara city. Further research can be carried out in other aspects of real estate sector viz. Commercial, Institutional, Industrial. Also research can be carried out to assess and manage the risks so as to sustain in the market after the completion of conceptualization stage.

\section{References:}

[1].Zhen-Yu Zhao, Lin-Ling Duan, An Integrated Risk Management Model for Construction Projects, PICMET 2008 Proceedings, 27-31 July, Cape Town, South Africa (c) 2008 PICMET

[2].Nur Alkaf Abd Karim, Ismail Abd. Rahman Aftab Hameed Memmon, Nurhidayah Jamil, Significant Risk Factors in Construction Projects: Contractor's Perception, 2012 IEEE Colloquium on Humanities, Science \& Engineering Research (CHUSER 2012), December 3-4, 2012, Kota Kinabalu, Sabah, Malaysia

[3].Prasanta Kumar Dey, decision support system for risk management:a case study, Emerald Journal, management decision (C) MCB university press [ISSN 0025-1747]

[4].Prof. Sakil S. Malik, Nazmeen I. Pathan, Harris Mal, risk management in construction indudstry, Volume : 3 | Issue : 6 | June 2013 | ISSN - 2249-555X

[5].Xian Li, The Analysis on Residential Real Estate Development Multi-objective Linear Programming and Decision, 978-1-4577-0536-6/11/\$26.00 @2011 IEEE

[6].Ana I. Irimia-Diéguez; Alvaro Sanchez-Cazorla, Rafaela Alfalla-Luque, Risk Management in Megaprojects, 18770428 @ 2014 IPMA.

[7].Kinnaresh Patel, A study on risk assessment and its management in India, American Journal of Civil Engineering 2013; 1(2): 64-67 Published online August 30, 2013 (http://www.sciencepublishinggroup.com/j/ajce) doi: 10.11648/j.ajce.20130102.13

[8].CROCKER H. LIU, JIANPING MEI, An Analysis of Real-Estate Risk Using the Present Value Model, Journal of Real Estate Finance and Economics, 8:5-20 (1994)_9 1994 Kluwer Academic Publishers

[9].Shuguo ZHANG, Ning XU, The Application of the Post-Evaluation of Residential Real Estate Project Based on Fuzzy Comprehensive Evaluation, ICCREM 2013 @ ASCE 2013

[10]. Virginia A Gibson, Risk Management and the Corporate Real Estate Portfolio, AMERICAN REAL ESTATE SOCIETY ANNUAL MEETING, 2002

[11]. Gianpaolo Abatecola*, Andrea Caputo, Michela Mari and Sara Poggesi, Real estate management: past, present, and future research directions, Int. J. Globalisation and Small Business, Vol. 5, Nos. 1/2, 2013

[12]. Li yancang,Suo Juanjuan, Zhou Shujing, mproved AHP model for real estate investment risk management, 2010 International Conference on E-Business and E-Government

[13]. Martin Hoesli, Elion Jani and Andre Bender, Monte Carlo simulations for real estate valuation, Journal of Property Investment \& Finance Vol. 24 No. 2, 2006 pp. 102-122 q Emerald Group Publishing Limited 1463-578X DOI $10.1108 / 14635780610655076$

[14]. Xiaoxin Liu, Xin Tian, Di Wu, Xiuting Li, Performance and Risk Management of Real Estate Enterprises, 2013 Sixth International Conference on Business Intelligence and Financial Engineering

[15]. David Gimpelevich, Simulation-based excess return model for real estate development, A practical Monte Carlo simulation-based method for quantitative risk management and project valuation for real estate development projects 
illustrated with a high-rise office development case study, Journal of Property Investment \& Finance Vol. 29 No. 2, 2011 pp. 115-144 q Emerald Group Publishing Limited 1463-578X DOI 10.1108/14635781111112765. 